\title{
Mean Platelet Volume Values and Its Effects on Prognosis in Patients with Acute Ischemic Stroke
}

\author{
Akut İskemik İnme Geçiren Hastalarda Ortalama Trombosit Hacmi \\ Değerleri ve Prognoza Etkileri
}

(D) Ülkü Figen Demir

İstanbul Yeni Yüzyıl University Faculty of Medicine, Gaziosmanpaşa Hospital, Clinic of Neurology, İstanbul, Turkey

\section{Abstract}

Objective: Stroke is a rapid onset of focal or global loss of cerebral function and is the most common cause of mortality and morbidity in adulthood cancer and heart disease patients. Although it has been reported that mean platelet volume (MPV) values may be an independent risk factor for the severity and prognosis of stroke, the results of previous studies are inconsistent. The aim of the present study was to determine the MPV values of ischemic stroke patients which reflects the activity and function of platelets and to observe its effect on clinical outcomes.

Method: Sixty-two acute ischemic stroke patients were recruited for the study. Clinical information, MPV, platelet, white blood cell (WBC) and neutrophil, CRP and troponin-T levels were obtained.

Results: The mean \pm standard deviation age was $72.4 \pm 12.6$ years. At the end of the study, 28 patients were discharged and 34 patients passed away. The frequency of bilateral stroke was higher in deceased patients $(p=0.005)$. In addition, platelet counts were significantly higher in discharged patients $(p=0.016)$. At first admission, MPV values were $10.59 \pm 1.01 \mathrm{fL}$ in discharged patients and 11.29 $\pm 1.12 \mathrm{fL}$ in deceased patients $(p=0.029)$. At the end of the study, MPV values were measured as $11.46 \pm 1.28 \mathrm{fL}$ in deceased patient sand $10.47 \pm 0.74 \mathrm{fL}$ in discharged patients $(p<0.001) . W B C$ and neutrophil counts, troponin- $T$ and CRP values were not significantly different between deceased and discharged patients ( $p>0.05)$.

Conclusion: Our study indicated that MPV and platelet levels may be associated with mortality in acute ischemic stroke patients and can be used as prognostic markers.

Keywords: Stroke, cerebrovascular diseases, MPV, platelet, prognosis

\section{Öz}

Amaç: İnme, ani başlangıçlı, fokal veya global serebral fonksiyon kaybıdır ve yetişkin çağ kanserleri ve kalp hastalıklarından sonra en sık mortalite ve morbidite nedenidir. Ortalama trombosit hacmi (MPV) değerlerinin inmenin şiddeti ve prognozu için bağımsız bir risk faktörü olabileceği bildirilmiş olmasına rağmen, önceki çalışmaların sonuçları tutarsızdır. Bu çalışmanın amacı, iskemik inme hastalarında trombositlerin aktivitesini ve fonksiyonunu yansıtan MPV değerlerini belirlemek ve bunun klinik sonuçlar üzerindeki etkisini gözlemlemektir.

Yöntem: Altmış iki akut iskemik inme hastası çalışmaya alındı. Klinik bilgi, MPV, trombosit, beyaz kan hücresi (WBC) ve nötrofil, C-reaktif protein (CRP) ve troponin-T düzeyleri elde edildi.

Bulgular: Ortalama yaş $72,4 \pm 12,6$ idi. Çalışmanın sonunda 28 hasta taburcu edildi ve 34 hasta eksitus oldu. Bilateral inme sıklığı ölen hastalarda daha yüksekti $(p=0,005)$. Ayrıca taburcu edilen hastalarda trombosit sayısı anlamlı derecede yüksek bulundu $(p=0,016)$. Illk başvuruda, MPV değerleri taburcu olan hastalarda 10,59 $\pm 1,01 \mathrm{fL}$ ve ölen hastalarda 11,29 $\pm 1,12 \mathrm{fL}$ idi $(p=0,029)$. Çalışmanın sonunda ölen hasta gurubunda MPV değerleri

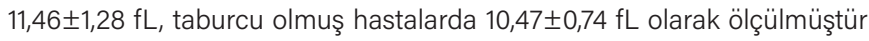
$(p<0,001)$. WBC ve nötrofil sayısı, troponin-T ve CRP değerleri ölen ve taburcu olan hastalar arasında anlamlı farklılık göstermedi $(p>0,05)$.

Sonuç: Çalışmamız MPV ve trombosit seviyelerinin akut iskemik inme hastalarında mortalite ile ilişkili olabileceğini ve prognostik belirteçler olarak kullanılabileceğini göstermiştir.

Anahtar kelimeler: İnme, serebrovasküler hastalıklar, MPV, trombosit, prognoz

Address for Correspondence: Ülkü Figen Demir, İstanbul Yeni Yüzyıl University Faculty of Medicine, Gaziosmanpaşa Hospital,

Clinic of Neurology, İstanbul, Turkey

E-mail: drfigendemir@gmail.com ORCID: orcid.org/0000-0002-2546-216X Received: 04.11.2019 Accepted: 04.12.2019

Cite this article as: Demir ÜF. Mean Platelet Volume Values and Its Effects on Prognosis in Patients with Acute Ischemic Stroke. Bagcilar Med Bull 2019;4(4):99-105

${ }^{\odot}$ Copyright 2019 by the Health Sciences University, Bagcilar Training and Research Hospital Bagcilar Medical Bulletin published by Galenos Publishing House. 


\section{Introduction}

Stroke is a rapid onset of focal or global loss of cerebral function and is the most common cause of mortality and morbidity in adulthood following cancer and heart disease patients (1). The prognosis of stroke varies from complete recovery in a couple of days to death. The incidence and mortality rate of stroke increases with age. The annual incidence of stroke was found to be 1.7-3.6/1000 in people aged between 55-64 years, 4.9-8.9/1000 in people aged between 65-74 years and 13.5-17.9/1000 in people over the age of 75 (2). With an aging population, stroke becomes a leading health problem in Turkey. Stroke is expected to increase exponentially in the coming years due to the progressive aging of population and also increasing prevalence of risk factors for stroke such as hypertension, diabetes, and obesity. Better understanding the effects of stroke-related risk factors on mortality and morbidity may help us to determine diagnosis, treatment, and prognosis of stroke.

Stroke is divided into two categories as ischemic and hemorrhagic. In a previous study conducted in Turkey, the rate of ischemic stroke was found to be $71.2 \%$ and the rate of hemorrhagic stroke was found to be $28.8 \%$ (3). When blood flow falls below a critical level, substrates such as oxygen and glucose begin to deplete in the brain tissue, and necrosis develops as neuron death occurs. Ischemic stroke develops as a result of atherothrombotic, embolic or hemodynamic processes. The atherothrombotic process, which includes fibrin production, platelet activation and disruption of fibrinolysis, plays an important role in the development of ischemic stroke (4).

Platelets are involved in hemostasis, thrombosis and coagulation processes. Circulating platelets are heterogeneous in size, density, and reactivity, and large platelets are more active metabolically and enzymatically (5). Large platelets produce a greater number of prothrombotic factors such as $\beta$-thromboglobulin, thromboxane B2, serotonin, glycoprotein IIIA, and P-selectin, and they are more prone to aggregate. Mean platelet volume (MPV) shows platelet size and it is an indicator of platelet function and activation. MPV levels have been studied in many pro-thrombotic and pro-inflammatory diseases and it has been reported that MPV could be an indicator that can be used to diagnose diseases such as acute cerebral ischemia and transient ischemic attack $(6,7)$. Despite the inconsistent results, previous studies conducted on stroke patients concluded that MPV may be an independent risk factor related to the severity and prognosis of the stroke.
In this study, we aim to determine the MPV values of acute ischemic stroke patients, which are indicative of activation and function of platelets and to examine the effects of MPV on the prognosis of ischemic stroke.

\section{Material And Methods}

The present study was designed as retrospective cohort study. Between January 2013 and May 2018, 62 patients who were admitted to the Emergency Clinic of Yeniyüzyıl University Faculty of Medicine, Gaziosmanpaşa Hospital with first or recurrent cerebral acute ischemic stroke and treated in the adult intensive care unit, were included. Systemic and neurological examination findings and the results of computerized brain tomography, electrocardiography, echocardiography (Echo) and carotid vertebral doppler ultrasonography of patients were obtained from patients' files. The results of Trans Esophageal Echo, cranial magnetic resonance imaging and cranial angiography were recorded as necessary in some cases. Demographic information and information about concurrent diseases such as hypertension, diabetes mellitus, chronic obstructive pulmonary disease, coronary artery disease, atrial fibrillation, and chronic renal failure were also recorded. In addition, clinical information such as the affected brain region and length of hospitalization were also obtained from the patients' files.

Patients with a history of acute or chronic infectious disease, hematological disorders (hemoglobin $>16.5 \mathrm{~g} / \mathrm{dL}$, thrombocytopenia, anemia, myeloproliferative disorder), cancer, autoimmune or metabolic disease, thrombosis, drug use, bone marrow disease, hypersplenism were excluded from the study. Also, pregnant patients and acute ischemic stroke patients whose MPV values were not determined at the time of admission were excluded.

\section{Biochemical Measurements}

We collected $5 \mathrm{~mL}$ blood samples from patients' antecubital veins at the time of admission and at the time of discharge. For complete blood count, tubes containing EDTA were used. For Troponin-T and C-reactive protein (CRP) measurements, blood samples were collected into tubes containing clot activator gel and were centrifuged for 10 minutes at $4000 \mathrm{rpm}$ for serum separation. Biochemical parameters were measured within 1 hour after blood collection. MPV, platelet count, white blood cell count (WBC) and neutrophil count values were obtained by complete blood count analysis. The results of complete blood counts were obtained by using the same SYSMEX 
$\mathrm{XN}-2000$ analyzer which uses the laser flow cytometry scattergram technique and routinely checked. CRP was measured by immunoturbidimetric method using Rochec501 device with the kit of the relevant company. Results greater than $5 \mathrm{mg} / \mathrm{dL}$ were considered as high level. Troponin-T levels were measured by using Roche Diagnostic Troponin-T kit according to the sandwich principle (ELISA) in the Roche c601 device.

\section{Statistical Analysis}

All statistical analyses were performed by using SPSS (Statistical Package for the Social Sciences) version 21.0 (SPSS Inc., Chicago, IL, USA). The conformance of quantitative data to normal distribution was checked by using the Shapiro-Wilk test. The descriptive statistics of the variables corresponding to the normal distribution were given as mean \pm standard deviation, and the other variables were given as median (minimum-maximum value). Descriptive statistics of qualitative variables were given as frequency and percentage. Intergroup comparisons of white cell, platelet and neutrophil variables suitable for normal distribution were performed by using t-test in independent samples. The values of the MPV variable, which were suitable for the normal distribution, were evaluated by two-way ANOVA analysis of variance in repeated measures. Age, length of stay, CRP and troponin variables that were not suitable for normal distribution were analyzed by using Mann-Whitney U test. Chi-square test was used to analyze the categorical data. $\mathrm{P}$ values equal to or under 0.05 were considered as statistically significant.

\section{Results}

Of those 62 patients, 28 (45.16\%) were females and 34 (54.84\%) were males. Participants were aged between 43 and 92 years. The mean age of the patients was $72.4 \pm 12.6$ years. At the end of the study, 28 patients were discharged and 34 patients died. The survival rate was not associated with age and with gender ( $p>0.05$ ) (Table 1). A concurrent disease was found in 59 patients (26 discharged patients and 33 deceased patients). There was no association between having an additional disease and survival $(\mathrm{p}=0.585)$. Twenty-two of 38 hypertension patients were deceased. Survival rates between hypertension patients and nonhypertension patients were not significantly different $(p=0.729)$. Atrial fibrillation was detected in eight patients. Seven of atrial fibrillation patients died. Having atrial fibrillation was found to be not associated with survival in ischemic stroke ( $\mathrm{p}=0.063)$. Table 1 shows the demographics and concurrent diseases of patients.

Thirteen patients had a right hemiparesis, 26 had a left hemiparesis and 23 had a bilateral stroke. Out of 23 bilateral stroke patients, 18 patients died. Bilateral stroke frequency was statistically significantly higher in deceased patients $(\mathrm{p}=0.005)$ (Table 2). Fifty-two $(83.87 \%)$ of the patients had acute cerebral stroke attacks for the first time and 10 (16.13\%) had their second attacks. Survival rates between first-time stroke patients and second-time stroke patients were not significantly different $(\mathrm{p}=0.097)$. The duration of hospitalization was 3-216 days in patients who were discharged and 4-839 days in patients who died. There was

\begin{tabular}{|c|c|c|c|c|}
\hline & Discharged $(n=28)$ & Deceased $(n=34)$ & Total $(n=62)$ & $\mathbf{p}$ \\
\hline Age & $72.5(44-88)$ & $74(43-92)$ & $73.5(43-92)$ & 0.708 \\
\hline Female & $14(50.00 \%)$ & $14(41.18 \%)$ & $28(45.16 \%)$ & 0.661 \\
\hline Male & $14(50.00 \%)$ & $20(58.82 \%)$ & 34 (54.84\%) & - \\
\hline Diabetes Mellitus & $10(35.71 \%)$ & 13 (38.24\%) & $23(37.10 \%)$ & 1.000 \\
\hline COPD & $3(10.71 \%)$ & $5(14.71 \%)$ & $8(12.90 \%)$ & 0.719 \\
\hline Coronary artery disease & $13(46.43 \%)$ & 15 (44.12\%) & $28(45.16 \%)$ & 1.000 \\
\hline Atrial fibrillation & $1(3.57 \%)$ & 7 (20.59\%) & $8(12.90 \%)$ & 0.063 \\
\hline
\end{tabular}

COPD: Chronic obstructive pulmonary disease

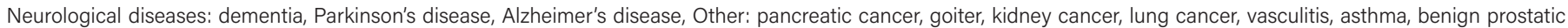

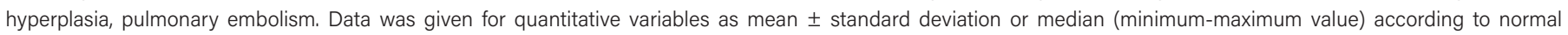
distribution suitability, and for qualitative variables as frequency (percentage). $\mathrm{P}<0.05$ was considered as statistically significant 
no statistically significant difference between these two groups regarding length of hospital stay $(\mathrm{p}=0.195)$.

At the time of hospital admission, platelet counts were $253.64 \pm 97.82 \times 10^{3} / \mathrm{mm}^{3}$ in discharged patients and $196.15 \pm 84.24 \times 10^{3} / \mathrm{mm}^{3}$ in deceased patients $(\mathrm{p}=0.016)$. WBC values were $11.75 \pm 4.59 \times 10^{3} / \mathrm{mm}^{3}$ in discharged patients and $11.40 \pm 4.57 \times 10^{3} / \mathrm{mm}^{3}$ in deceased patients ( $>>0.05)$. In addition, neutrophil values were measured as $8.84 \pm 3.92 \times 10^{3} / \mathrm{mm}^{3}$ in discharged patients and $9.57 \pm 4.39 \times 10^{3} / \mathrm{mm}^{3}$ in deceased patients $(\mathrm{p}>0.05)$. Also, there was no statistically significant difference between discharged and deceased patients regarding Troponin-T and CRP levels (Table 3). The biochemical measurement results were shown in Table 3.

At the time of the first admission, MPV values were $10.59 \pm 1.01 \mathrm{fL}$ in discharged patients and $11.29 \pm 1.12 \mathrm{fL}$ in deceased patients $(\mathrm{p}=0.029)$. At the end of the study, we found that MPV values of deceased patients $(11.46 \pm 1.28$ fL) were significantly higher than discharged patients $(10.47 \pm 0.74 \mathrm{fL})(\mathrm{p}<0.001)$.

\section{Discussion}

The aim of this study was to determine MPV values in acute ischemic stroke patients and to investigate its effect on the prognosis of ischemic stroke. Our study showed that deceased patients had higher MPV values than survived patients. As a consequence, MPV may have an importance in determining the prognosis of acute ischemic stroke.

Epidemiological studies have identified predisposing risk factors for stroke, and have shown that stroke risk can be reduced by treatment and modification of these risk factors $(2,8,9,10,11,12,13)$. It has been shown that the risk of stroke increases with the progression of age, and $70 \%$ of people with stroke are older than 65 years (8).

Consistent with the literature, our study was included elderly patients and the mean age of the patients was $72.4 \pm 12.7$ years. Modifiable risk factors for stroke include diseases such as hypertension, diabetes mellitus, atrial fibrillation, hyperlipidemia, asymptomatic carotid stenosis, and habits like smoking and alcohol use. It has been shown that the decrease in systolic blood pressure

\section{Table 2. Clinical characteristics of the patients}

$$
\text { Discharged }(n=28)
$$

Decreased $(n=34)$ Total $(n=62)$

$13(20.97 \%)$

$26(41.94 \%)$

$23(37.10 \%)$

$3(8.82 \%)$
$13(38.24 \%)$

$18(52.94 \%)$

$52(83.87 \%)$

$10(16.13 \%)$

$2(7.14 \%)$

$26(76.47 \%)$

$\begin{array}{ll}8(23.53 \%) & 10(16.13 \%) \\ 15.5(4-839) & 14(3-839)\end{array}$

p

0.005

\section{Number of CVD}

Second

Length of stay

CVD: Cerebrovascular diseases

Data was given for quantitative variables as mean \pm standard deviation or median (minimum-maximum value) according to the normal distribution suitability, and for qualitative variables as frequency (percentage). $\mathrm{P}<0.05$ was considered as statistically significant.

Table 3. Biochemical analyses results

\begin{tabular}{|c|c|c|c|c|}
\hline & Discharged $(n=28)$ & Deceased $(n=34)$ & Total $(n=62)$ & $\mathbf{p}$ \\
\hline Platelet (x1000) & $253.64 \pm 97.82$ & $196.15 \pm 84.24$ & $222.11 \pm 94.37$ & 0.016 \\
\hline White cell (x1000) & $11.75 \pm 4.59$ & $11.40 \pm 4.57$ & $11.56 \pm 4.54$ & 0.769 \\
\hline CRP & $27.96(1.2-336)$ & $64.3(1.6-257.7)$ & $34.73(1.2-336)$ & 0.132 \\
\hline Troponin-T & $0.042(0.007-0.452)$ & $0.081(0.014-3.490)$ & $0.073(0.007-3.490)$ & 0.053 \\
\hline Last & $10.47 \pm 0.74$ & $11.46 \pm 1.28$ & $10.98 \pm 1.15$ & 0.001 \\
\hline
\end{tabular}

CRP: C-reaktifprotein, MPV: Mean platelet volume

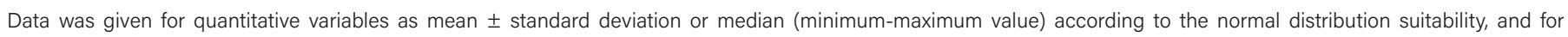
qualitative variables as frequency (percentage). $\mathrm{P}<0.05$ was considered as statistically significant 
by $10 \mathrm{mmHg}$ and diastolic blood pressure by $5 \mathrm{mmHg}$ reduces the risk of stroke by $30-40 \%$ (9). Also consistent with the literature, $95 \%$ of our study group had comorbid diseases and $61 \%$ of them had hypertension. However, our study showed no association between hypertension and survival in acute ischemic stroke. Patil et al. (7) conducted a hospital-based cross-sectional study in 79 stroke patients (25 diabetics and 54 non-diabetics). They found that MPV values were to be higher in the diabetic group. In a prospective study of 200 diabetic patients conducted by Han et al. (10), it was shown that after 28.4 months of follow-up, 14 patients developed ischemic stroke and eight patients developed coronary artery disease. Further, stroke and coronary artery disease development rates were higher in patients with high MPV values. In the same study, it was proposed that MPV is a predictive factor for stroke and coronary artery disease development, independent of age, gender, hypertension, and HbAlc values. In our study, 23 patients had diabetes mellitus as a concurrent disease. In contrast to Han et al. (10)'s study, we did not observe any effects of diabetes mellitus on survival of acute ischemic stroke patients. An association between stroke and atrial fibrillation as a predisposing factor has been shown in various previous studies $(11,12)$. In a prospective study that followed up 90 paroxysmal atrial fibrillation (PAF) patients, it has been observed that 31 patients developed stroke (11). The same study concluded that MPV levels may help to determine the increased risk of developing acute or transient ischemic attacks in patients with PAF. In a study comparing 63 stroke-atrial fibrillation patients and 77 non-stroke atrial fibrillation patients, it was determined that MPV values bigger than 9.4 were associated with stroke development. The aforementioned study indicated an increased risk for stroke in patients with atrial fibrillation according to ROC analysis data (12). In our study, seven of eight atrial fibrillation patients passed away after getting an acute ischemic stroke attack. However, our study showed no association between atrial fibrillation and survival in ischemic stroke $(p=0.063)$. In our study, we found the mortality rate to be high. This may be due to the fact that the number of patients is high with bilateral affected brain region in the deceased group. It may also be due to the high number of patients with atrial fibrillation in the dying group.

Previous studies that investigated the impact of MPV levels on prognosis of stroke patients showed different results. In a study conducted by Farah and Samra (13) in 2018, no association was found between MPV values of stroke patients and development risk of a new stroke attack. In the study with 136 participants by $\mathrm{Oz}$ et al. (14), it was found that MPV has no value in predicting the development of a cerebrovascular event in coronary artery disease. In addition, a previous study which compared MPV values of 70 first time atherothrombotic acute ischemic stroke patients, 50 transient ischemic attack patients, and 70 healthy individuals, no statistically significant difference was found between the groups (15). Another study by Nataios et al. (16) measured MPV values within the first 24 hours after the onset of stroke and found that MPV levels were not associated with stroke severity and limitation of neurological functions. Further, a retrospective study by Lok et al. (17) in 2017 which 798 first time acute ischemic stroke patients participated, showed that MPV values were not associated with short-term stroke prognosis and neurological functions. Also, a study compared MPV values of 281 first-episode acute ischemic stroke and 164 first-episode hemorrhagic stroke patients and found that MPV values were high in both groups but it is not associated with the prognosis (5). In contrast, in a 2017 study conducted on 100 acute cerebral infarction patients and 80 healthy controls by Wan and Ma (18), it was found that MPV values were high in the patient group. The same study suggested that MPV may have the potential to be a sensitive index for the prediction of acute cerebral infarct prognosis. Similarly, a study conducted on 776 patients with acute or transient ischemic attacks by Greisenegger et al. (6) which evaluated patients with Rankin scale after one week from the stroke attack, observed that higher MPV values were associated with worse clinical outcomes. In addition, a correlation between high MPV values and severity of stroke was observed in a study which 100 first time stroke patients participated. The same study suggested that this finding could be used to differentiate between mild and severe ischemic stroke (19). Furthermore, Arikanoglu et al. (20) found that MPV levels were high in 63 acute ischemic stroke patients. Also, a previous study observed that patients who passed away within 10 days after the acute ischemic stroke attack had higher MPV values than survivors, and suggested that it could be used as an indicator for mortality. In a prospective study conducted by Arévalo-Lorido et al. (21), MPV values of 379 stroke patients were examined. As a result of the study, it was found that those with high MPV (>12) had low survival or high rate of re-hospitalization, and functional disabilities were developed mostly in this group. Another study also conducted by Arévalo-Lorido et al. (22) in 215 atherothrombotic stroke patients, observed 
an association between high MPV values and severity of carotid stenosis. Moreover, a study which included 692 patients with ischemic or hemorrhagic stroke and 208 healthy controls, high MPV level was found to be an independent risk factor for the development of ischemic stroke, and was associated with poor prognosis, but not with the risk of hemorrhagic stroke (23). In a previous prospective study which 3134 patients participated, 402 ischemic events in 383 patients were observed and found that the risk of stroke attack increased $11 \%$ in patients with high MPV values (24). In parallel with some mentioned studies, we observed worse clinical outcomes in acute ischemic stroke patients with higher MPV levels in our study. Our result suggests that high MPV levels may be considered as a risk factor in patients with acute cerebral ischemic stroke, and may be associated with high morbidity and mortality. It also indicates that high MPV levels may be used as an indicator to differentiate severe ischemic stroke from mild ischemic stroke. According to our study's results MPV which is an easily obtained blood parameter may be an indicator of poor prognosis and high mortality. We also observed that platelet count was higher in survived patients than deceased patients. When we evaluate our results on MPV and platelet count together, we suggest that there may be a connection between platelet dysfunction and poor stroke prognosis.

Also, some previous studies suggest that MPV values can be used for predicting the treatment outcomes in ischemic stroke patients. In a 2018 study conducted by İnanç et al. (25), MPV values of 129 stroke patients were found to be associated with neurological scale score improvement after intravenous thrombolytic therapy. In addition, a previous study by $\mathrm{Ha}$ et al. (26) in which 200 atrial fibrillation patients participated, suggested that MPV is a predictive factor for stroke development, independent of age and gender. They also suggested that anticoagulation treatment may be necessary for patients with high MPV values, even if they have low or moderate thromboembolic risk for a stroke attack. A 2017 study evaluated elevated MPV levels of 196 non-cardioembolic ischemic stroke patients before clopidogrel treatment as a risk factor for ischemic stroke treatment resistance (27). Similarly, we found higher MPV values in deceased patients both before and after the treatment. Considering this finding, we suggest that high MPV values may be an important factor for treatment resistance and can be used as an independent predictor of poor prognosis in ischemic stroke patients.
Previous studies showed that the effects of a stroke attack depend on the part and size of the brain area affected. Pikija et al. (28) found that high MPV level was independently associated with greater infarct volume, and its value at $7^{\text {th }}$ day and third month after stroke was associated with increased risk of death in 81 acute ischemic stroke patients. Similarly, we observed that stroke patients with bilateral hemisphere involvement had an increased risk of death.

\section{Conclusion}

This study showed that MPV and platelet count may be associated with survival rate in acute ischemic stroke patients, and may be used as prognostic indicators. With conforming future large-scale prospective studies in stroke patients, our findings may lead to better clinical follow-up and a more extensive understanding of stroke pathogenesis.

\section{Ethics}

Ethics Committee Approval: Retrospective study.

Informed Consent: Retrospective study.

Peer-review: Externally peer-reviewed.

Financial Disclosure: The author declared that this study received no financial support.

\section{References}

1. World Health Organization (1978) Cerebrovascular Disorders: A Clinical and Research Classification. WHO Offset Publication, Geneva.

2. Bonita R. Epidemiology of stroke. The Lancet 1992;339:342-344.

3. Gazi Ö, Serhat Ö, Nevzat U. Türkiye'de beyin damar hastalıkları için major risk faktörleri. Türk Beyin Damar Hastalıkları Dergisi 2000;6:31.5.

4. Ayas ZÖ, Can U. Alteration of mean platelet volume in the pathogenesis of acute ischemic stroke: cause or consequence? Ideggyogyaszati szemle 2018;71:49-56.

5. Du J, Wang Q, He B, Liu P, Chen JY, Quan H, et al. Association of mean platelet volume and platelet count with the development and prognosis of ischemic and hemorrhagic stroke. International journal of laboratory hematology 2016;38:233-239.

6. Greisenegger S, Endler G, Hsieh K, Tentschert S, Mannhalter C, Lalouschek W. Is elevated mean platelet volume associated with a worse outcome in patients with acute ischemic cerebrovascular events? Stroke 2004;35:1688-1691.

7. Patil P, Darshan A, Saroja A, Kothiwale V. Association of Mean Platelet Volume with Acute Ischemic Cerebrovascular Accident Among Patients with Type 2 Diabetes Mellitus: A Hospital-Based Study. Journal of The Association of Physicians of India 2018;66:4447.

8. Guzik A, Bushnell C. Stroke epidemiology and risk factor management. CONTINUUM: Lifelong Learning in Neurology 2017;23:15-39 
9. D'Agostino RB, Wolf PA, Belanger AJ, Kannel WB. Stroke risk profile: adjustment for antihypertensive medication. The Framingham Study. Stroke 1994;25:40-43.

10. Han JY, Choi DH, Choi SW, Kim BB, Ki YJ, Chung JW, et al. Stroke or coronary artery disease prediction from mean platelet volume in patients with type 2 diabetes mellitus. Platelets 2013;24:401-406.

11. Bayar N, Arslan S, Cagirci G, Ureyen CM, Cay S, Yuksel IO, et al. Usefulness of mean platelet volume for predicting stroke risk in paroxysmal atrial fibrillation patients. Blood Coagulation \& Fibrinolysis 2015;26:669-672.

12. Turfan M, Erdogan E, Ertas G, Duran M, Murat SN, Celik E, et al. Usefulness of mean platelet volume for predicting stroke risk in atrial fibrillation patients. Blood Coagulation \& Fibrinolysis 2013;24:55-58.

13. Farah R, Samra N. Mean platelets volume and neutrophil to lymphocyte ratio as predictors of stroke. Journal of clinical laboratory analysis 2018;32:e22189.

14. Oz II, Yucel M, Bilici M, Şerifoğlu İ, Sayın R, Ilikhan SU, et al. Is mean platelet volume a reliable marker to predict ischemic stroke in the follow-up of patients with carotid stenosis? Journal of Stroke and Cerebrovascular Diseases 2016;25:404-409.

15. Celikbilek A, Ismailogullari S, Zararsiz G. Neutrophil to lymphocyte ratio predicts poor prognosis in ischemic cerebrovascular disease. Journal of clinical laboratory analysis 2014;28:27-31.

16. Nataios G, Gurer O, Faouzi M, Aubert C, Michel P. Mean platelet volume in the early phase of acute ischemic stroke is not associated with severity or functional outcome. Cerebrovascular Diseases 2010;29:484-489.

17. Lok U, Gulacti U, Ekmekci B, Bulut T, Celik M. Predictive and prognostic role of mean platelet volume in patients with first-ever acute ischemic stroke. Neurosciences 2017;22:119-126.

18. Wan JL, Ma ZW. The Value of Mean Platelet Volume for Prognosis of Patients with Acute Cerebral Infarction. Clinical laboratory 2017;63:1801-1807.

19. Ghahremanfard F, Asghari N, Ghorbani R, Samaei A, Ghomi H, Tamadon M. The relationship between mean platelet volume and severity of acute ischemic brain stroke. Neurosciences 2013:147151.
20. Arikanoglu A, Yucel Y, Acar A, Cevik M, Akil E, Varol S. The relationship of the mean platelet volume and C-reactive protein levels with mortality in ischemic stroke patients. Eur Rev Med Pharmacol Sci 2013;17:1774-1777.

21. Arévalo-Lorido JC, Carretero-Gómez J, Álvarez-Oliva A, GutiérrezMontaño C, Fernández-Recio JM, Najarro-Díez F. Mean platelet volume in acute phase of ischemic stroke, as predictor of mortality and functional outcome after 1 year. Journal of Stroke and Cerebrovascular Diseases 2013;22:297-303.

22. Arévalo-Lorido J, Carretero-Gómez J, Villar-Vaca P. Mean platelet volume predicting carotid atherosclerosis in atherothrombotic ischemic stroke. Irish journal of medical science 2012;181:179-183.

23. Mayda-Domaç F, Misirli H, Yilmaz M. Prognostic role of mean platelet volume and platelet count in ischemic and hemorrhagic stroke. Journal of Stroke and Cerebrovascular Diseases 2010;19:6672.

24. Bath P, Algert C, Chapman N, Neal B. Association of mean platelet volume with risk of stroke among 3134 individuals with history of cerebrovascular disease. Stroke 2004;35:622-626.

25. İnanç Y, Giray S, İnanç Y. Mean platelet volume, C-reactive protein, and prognosis in patients with acute ischemic stroke following intravenous thrombolytic treatment. Medical science monitor: international medical journal of experimental and clinical research 2018;24:3782-3788.

26. Ha SI, Choi DH, Ki YJ, Yang JS, Park G, Chung JW, et al. Stroke prediction using mean platelet volume in patients with atrial fibrillation. Platelets 2011;22:408-414.

27. Li W, Xie X, Wei D, Zhang S, Wu Y, Fu X, et al. Baseline platelet parameters for predicting early platelet response and clinical outcomes in patients with non-cardioembolic ischemic stroke treated with clopidogrel. Oncotarget 2017;8:93771-93784.

28. Pikija S, Cvetko D, Hajduk M, Trkulja V. Higher mean platelet volume determined shortly after the symptom onset in acute ischemic stroke patients is associated with a larger infarct volume on CT brain scans and with worse clinical outcome. Clinical neurology and neurosurgery 2009;111:568-573. 